\title{
Multiple burials in ancient societies: theory and methods from Egyptian archaeology
}

\author{
Gianluca Miniaci
}

\begin{abstract}
The paper aims at providing theoretical models and data interpretation applied to multiple burials. Challenging the current fuzzy definition of multiple burials in ancient societies, the paper proposes a more accurate classification of multiple burials, with particular reference to ancient Egypt funerary culture, based on two main parameters, which may have influenced the association of bodies: p1) architecture; p2) time span; and three flexible sub-parameters that may be used to customize different scenarios, on occasion: sp1) number of deceased; sp2) age of deceased; sp3) nature of death/deposition. The body has been often considered the real ontological centre of the burial itself with, on the other hand, all of the other countable objects, intended as radiating projections supporting the body-nucleus. The practice of multiple burials disrupts such a perception as it juxtaposes horizontal, multidirectional perspectives: the role of a new body entering with older bodies and objects, and of the multiple bodies and objects among them. The study of multiple burials, if correctly framed, can lead to insights on different religious, social, and economic reasons behind the mortuary programs within a society. For instance, sequential multiple burials reinforce the transformation of dead bodies into part of the burial equipment itself, reducing the centrality of the body and disrupting the narrative tied to individual biographies, increasing an 'artefactual' perception.
\end{abstract}

A grave, although made by several material and immaterial constituent layers including, for instance, objects, architectural structures, funerary rituals and remembrance acts (Kellehear 2007), is pragmatically intended as a place or a container for the body of the deceased. ${ }^{1}$ In the logic of burial assemblage, the body (as corpse/identity/accumulation of social relations) has been seen as the element that provides the raison d'être for the burial itself; the other elements of the burial are considered secondary additions, intended as radiating projections supporting the body-nucleus. This has created an imbalance in the logic of indexing the different constituents of the grave itself. Therefore, scholars have usually tended to dichotomise the ensemble of the grave into two broad different categories: on the one hand, there is the body -as the real ontological centre of the burial itself- and, on the other hand, all of the other countable objects, which were influential or created especially for shaping the mortuary ideology. Such a dichotomy between human remains and other objects, and their relative contextual isolation, was already grounded from the early days of archaeological documentation, where the two units were usually separated from each other for the pragmatic purposes of recording and interpretation. For instance, in the Roman Period cemetery of Hawara in the Egyptian Fayum Oasis, Flinders Petrie proceeded to remove (the famous) painted portraits, masks and painted shrouds from their mummies, splitting the burial unit in several separated parts, with the bodies, and above all the skulls, destined for a very different fate than the body coverings (Riggs 2014, 41-76, esp. 60). The 'uncanny' nature of the Egyptian mummy has accentuated such a dichotomy, since the exceptional preservation of

\footnotetext{
${ }^{1}$ Not all the burials necessitate the full presence of the body, as for instance in cremation (Sprague 2005, 57-9). In addition, according to Judith Butler's theory of performativity, body materialisation is something that happens culturally, even in the absence of the corpse itself (Butler 1993, 113-14). The most common example of this notion is the existence of cenotaphs -funerary structures which do not contain any body- present in numerous societies, including ancient Egypt (O' Connor 1985). Although deprived of the materiality of the body, cenotaphs fall into the burial category because they still encapsulate the identity (or the collective identity) of the deceased. Also linguistically, cenotaphs markedly express only an adjectival -and not a structural- modification to the term 'grave', adding the prefix, kenos, meaning 'empty', to the term taphos 'grave'.
} 
the human body, including facial features, has had the result of uprooting bodies from the archaeological context in favour of an association with ethnographic material (as demonstrated by Riggs 2016). The separation of bodies and objects is intensified by a distinction deeply ingrained into social sciences between 'animate subjects that belong to the cultural world' and 'inanimate objects that are part of the material world' (Sofaer 2006, 62), where 'cultural' is associated with biological/animation and 'material' with lifelessness (see also Schiffer 1987 and Holliday 2004 for the distinction between cultural and non-cultural i.e. natural- processes in site formation). Although, in the first instance, the 'body' may be intuitively associated with the animate subject and the cultural world, it does not have clearcut boundaries, since it suffers from the dual -often-counteractive- biological/cultural overlay (Butler 1993, 1-23). Therefore, a human body tended to be perceived as composed by two opposite elements: a physical body and a spiritual or intellectual soul/mind ( $c f$. Benthien 2002; Shilling 2008). The dualistic approach was based on two -often separated and undialectical-disciplines: a) human biology which is grounded in the empirical sciencebased documentation of sexing, ageing, diet, genetic, pathology, metric variations, and b) social theory, which perceives the body as a more fluid element shaped by social-cultural elements (Sofaer 2006, 1-11; on the dialogue between these disciplines see Hallam, Hockey \& Howarth 1999; Armelagos 2003). From the naturalistic perspective, once dead, the body becomes a sort of empty shell deprived of its spiritual connections and therefore without agency power in the living world. From the cultural point of view, vacant corpses are perceived as the results of the accumulation of social relations exercised during life (Turner 2011; Fowler 2013); therefore, their reinsertion into the social context by other living people is dictated by functional and affective scopes (Bindord 1971; Meskell 1998; Tarlow 1999; Fowler 2002; critique in Robb 2013). Although recently the hybrid concept of 'biological objects' applied to dead bodies has tried to dominate and explain the contradictory nature of the human body (Ingold 1998, 35; Sofaer 2006, 69), it actually has had the opposite effect and reinforced even more the separation between the body's uniqueness and the associated objects in a burial.

Therefore, such a dichotomy has often led archaeology towards autonomous and separate analyses of the two units - objects on one side and bodies on the other. The development of disciplines mainly based on the analysis of human remains (archaeothanatoloy, forensic bioarchaeology, osteoarchaeology, funerary taphonomy; Duday 2006; Knüsel 2010; Schotsmans, Márquez-Grant \& Forbes 2017) seems to compensate for the large attention paid to the objects by archaeology, but not to generate a full integration. However, even in the attempts of dialogue among the two units, scholars tended to impose a hierarchical, vertical relationship between the body and the object (Ekengren 2013), generating unidirectional focuses either on the grave equipment, isolating the human remains, or -vice versa- on the human remains, overshadowing the analysis of the surrounding features. The presence of multiple bodies and disparate funerary equipment in a single grave generates a certain degree of ambiguity and difficulty in structuring the context, because it juxtaposes horizontal, multidirectional perspectives (Duncan \& Schwarz 2014): the role of a new body entering with older bodies and objects, and of the multiple bodies and objects among them (also in terms of an internal relative chronology; cf. Goldstein 1981). Taphonomic approaches to multiple burials have been more intended to produce empirical observations and analytic analyses of the archaeological and osteological contexts (Loendorf 1998; Duday 2009), rather than generating methodologically structured information. As a consequence, they failed in providing a common, standardised and unambiguous language for the diversity of cases ( $c f$. Boulestin \& Duday 2005; Knüsel 2014, 43-5). Duday attempted to provide a definition of some basic terms, distinguishing between 'plural burials', a generic term for several individuals in the same structure (Leclerc \& Tarrête 1998), 'multiple burials' for several 
bodies deposited simultaneously in the same structure, and 'collective burials' for the depositions staggered over a long period of time in the same structure (Duday 2008, 50; followed by Castex \& Blaizot 2017, 284-94). However, researchers continue to refer to burials containing more than one individual using a fluctuating scientific terminology: double, twin, triple, plural, mixed, mass, mass bundle, multiple, pattern, ossuary, group, and collective burials (Stoodley 2002; Sprague 2005, 73-4, with bibliography).

\section{Definition of 'multiple' + 'burial'}

In dictionaries and encyclopaedias, the locution multiple burial/grave indicates a single funerary structure where two or more individuals ${ }^{2}$ (or interments) are buried together. Already from the outset of any analysis, a clear-cut archaeological definition of 'grave', and even more of the term 'burial', is elusive (Sprague 2005, 60; Knüsel \& Robb 2016, 657). Although constantly employed, the term 'burial' can be highly misleading, since it merges together the dualism of mechanical and cultural languages, where layers of immateriality (social relations, acts, gestures, rituals) overlap with the tangible parts of an interment (physical spaces, structures, deceased bodies). The term 'burial' has been explained as the 'result of a series of ritualised practices performed in relation to death' (Oestigaard \& Fahlander 2008, 2), which does not necessarily imply the generation of material evidence, even though 'burial' can refer to the construction of a grave or the presence of a body. Therefore, in order to release the concept of 'burial' from its immaterial confines, the term 'grave' is more suitable to indicate -from a solely structural point of view- any tangible space ('feature') used to accommodate the deceased, which can range from a simple hole dug in the ground to a shrine (Knüsel \& Robb 2016, 657). In addition, the use of the prenominal attributive adjective 'multiple' increases semantic confusion, above all in Egyptological literature, where there are no specific studies on the subject ${ }^{3}$ ( $c f$. Seidlmayer 1990, 398-430; Grajetzki 2007; Miniaci forthcoming a). The degree of variation between different types of burials is remarkable, yet the term 'multiple burial' is often used unconstrained without any further specification other than the mere numerical relationship: number of 'individual(s) vs structure'. Does funerary architecture alone represent the watershed between single and multiple graves? Should not age, nature of death, and time also play a role in accounting for the number of deceased in a grave? For instance, a mother buried with her child can be hardly considered a multiple burial in the same way as a grave containing three adult corpses. Furthermore, burials with dozens or hundreds of individuals are structurally different from interments comprising a handful of persons. Therefore, within the large corpus of 'multiple burials', deep conceptual differences can be highlighted as a result of the differences in the methodologies used to associate one or more bodies within a grave.

In seeking to generate a more inclusive and flexible set of terms for different types of multiple burials, I focus here on ancient Egypt, which offers an abundance of organic material preservation (including coffins) and of written sources (including names and genealogies). These two factors in combination with the wealth of archaeological records provide a solid foundation from which to establish the boundaries of each category. I look particularly at the period 1800-664 BC (corresponding to the late Middle Kingdom till the Third Intermediate Period), a broad time period in which multiple burials became more

\footnotetext{
2 La Fontaine uses the term 'individual' to refer to the 'mortal human being' and 'person' to refer to the 'concepts which give it social significance' (La Fontaine 1985, 123-40). This does not imply that individuals were not endowed with agency, as they were 'component social actors' (see Moore 2000, 260).

${ }^{3}$ Such a gap can be also caused by the lack of detailed information in the archaeological reports produced in the nineteenth and twentieth centuries, which form much of the foundation of modern Egyptian archaeology.
} 
widespread across the whole country and were more visible at all social levels, reaching the uppermost segments of society and, in certain instances, the royal court. In the preceding time span (3200-1800 BC = Early Dynastic-Middle Kingdom) ancient Egyptians privileged individual burials to a greater degree.

\section{The parameters behind a multiple burial assemblage}

I identify here two main parameters which may influence how bodies come to be associated together in a single feature: p1) architecture of the feature; p2) temporality. Three other sub-parameters may alter or recast points p1-2: sp1) number of individuals; sp2) age of individuals; sp3) nature of death/deposition. I am aware that any attempt at classification can generate models and theory that overlook historical reality and that cannot be applied without reference to localised systems of meaning (Morris 1991, 147-8): each single case is subject to specific contingencies of everyday life or is tied to broad cultural variations from one region to another, from one epoch to another, from one social level to another. Nonetheless, the isolation of theoretical patterns for body distribution inside multiple interments may lead scholars to move away from a static dichotomy: single body vs. multiple bodies, towards greater recognition of the variations in multiple body assemblages and of their meanings (cf. Waterman \& Thomas 2011). Different religious, social, and economic reasons may lie behind a burial demography that reflects the mortuary programs of a society (Osterholtz, Baustian \& Martin 2014, 1-13). The further development of theoretical frameworks may also contribute to comparative exploration of the rationale behind bodies' association in different cultures and times. For instance, Osterholtz noticed an increase in multiple individuals in single graves during the Protostoric Bronze Age III (1300-1050 BC) at Cyprus, perhaps connected with the use of lineage or family-based tombs (Osterholtz 2015, 259). At approximately the same time, between the end of the New Kingdom and the Third Intermediate Period (eleventh century BC), Egypt saw broad use of multiple burials across all its territory. Although at first sight these two phenomena could be related, the type of association of bodies in the two cases is completely different, as the logic behind the multiple burials in Egypt is driven by reduced economic power and a contraction of building activity, leading towards the reuse of older structures (Taylor 2010).

\section{Parameters p1-2}

\section{p1. Architecture (types $a-b$ )}

The architecture of the grave is the essential element that may create a strong divide across different types of burials. Architectural isolation represents the conditio sine qua non for multiple burial definition, i.e. more bodies in an individual grave. However, architectural isolation is variably changing according to the frame of reference. For instance, in area A in the floodplain of Dra Abu el-Naga hill (Thebes, modern Luxor) are a number of 1600-1500 $\mathrm{BC}$ graves cut into the ground and structured around 'free-standing' chapels, called by the excavators 'Freistehende Grabbauten'. They have been often identified as multiple burials. However, although shaft graves are clearly all grouped under a common architectonic structure -a free standing chapel-, which acts as a cult as well as symbolic benchmark, the graves are all built separately with their own entrance, and each displays a different ratio in the number of individuals and array of burial equipment; thus, each has its own individual relationship 'number of individuals-grave' (Polz 2007, 239-45; Fig. 01). This example and similar cases go far beyond the concept of the multiple burial, since stricto sensu a 
'cemetery' should also be considered as a multiple burial, as it marks a common cult and symbolic environment.

Therefore, the multiple burials shall be characterised by architectural isolation in se and the number of individuals should be counted in each separate grave. For architectural isolation is intended any coherent form of structure built with the purpose of separating the body and its funerary equipment from the surrounding environment. As in ancient Egypt, body protection is often an integral part of the burial equipment and wooden coffins, textile, mat envelops, mud and pottery containers are conceived to be placed inside an architectural structure (whether a pyramid or a simple pit dug into the ground); they cannot be considered an architectural feature. Even in isolated architectural features, there could be ambiguous cases: for instance, a single grave with one entrance (such as a shaft) can lead to several but separate burial chambers which each containing a single deceased person. Here the minimum requirement for classification as a multiple burial changes according to the point of view: external $=$ several bodies grouped under a single structure; internal = bodies in a single structure clearly separated from each other by defined underground architecture. Therefore, I propose that a distinction should be made between a. 'direct multiple burials', b. 'indirect multiple burials'.

Direct multiple burial (type a). 'Direct multiple burials' indicate more than one body grouped in a single funerary space, which is not only architectonically but also ideologically and intentionally well separated from other burial spaces. For instance, Hogarth's tomb 19 in the cemetery at Sheikh Abu Togh (Asyut) comprises a small independent rock cut chapel leading to a large burial chamber arranged on two levels, one at the same height as the chapel floor and another sunk slightly below that level (Zitman 2010, vol. I, 108; vol. II, 29, plan 10). According to the archaeological context and excavator's information, four coffins were discovered in a single burial place, three of which lay one on top of the other (Fig. 02). The four burials all belong to a narrow sequential time span (cf. type g) from ca. 2150 to $2000 \mathrm{BC}$, and no traces of later disturbance (contra type $\mathbf{h}$ ) after the last interment were found.

Indirect multiple burial (type b). 'Indirect multiple burials' feature individual interments, which may be separated from each other by an architectural element (such as a door, a wall, earth, or any type of blockade) but which are, nonetheless, intentionally and ideologically connected within a unique funerary space. Thus, this type of multiple interment, while maintaining the conceptual idea of multiple burials, nevertheless achieves the isolation of the bodies. For instance, tomb 954 at Lisht (at the geographical entrance to the Fayum) consists of a single shaft entrance and radiating from the shaft on each of three different levels an arrangement of six compartments, each one accommodating a single body, thus allowing altogether room for eighteen individuals (Fig. 03). The blocking of the two upper levels was found still intact and the burials undisturbed, while the six compartments of the bottom level, clearly created to accommodate human bodies such as those above, were for unknown reasons left vacant and unused (Arnold 2007, 83, pl. 159c-e). The empty compartments indicate that the structure was originally conceived as a multiple burial place, although with an explicit separation of the bodies in the underground rooms. ${ }^{4}$

\section{p2. Temporality (types $c-h$ )}

Temporality is one of the key factors that regulate funerary processes. An essential division, which involves temporality, is made between 'primary' (type c) and 'secondary' (type d) burials.

\footnotetext{
${ }^{4}$ In the 1800 BC cemeteries of Lisht and Dahshur there are several examples of isolated inhumations arranged in underground rooms around a unique entrance off the shaft (cf. Arnold 1992, 41-6, pls. 52-4; Arnold 2002, 6974, pls. 69-70).
} 
Primary burial (type c). In 'primary burials' the individuals are deposited in their original place of interment and they were not moved or otherwise manipulated afterwards. Secondary burial (type d). In 'secondary burials' the individuals had been moved from their original interment location and re-deposited in a different place (Andrews \& Bello 2006, 17; Boz \& Hager 2014, 18-20; Osterholtz, Baustian \& Martin 2014, 8-9; Knüsel 2014, 46-8). For instance, three individuals, one female adults and two children, were deposited, presumably as primary interments, in one of the graves of the South Tombs Cemetery at Amarna (the main city during the reign of Akhenaton, 1349-1332 BC); together with them was a fourth individual (female; Ind. 90), buried as a disarticulated assemblage of bones, 'padded out with mud-brick, pottery and a roll of matting to restore its shape' (Stevens 2017, 115, fig. 13). The way in which individual no. 90 was found indicates that it was buried, unearthed, and buried again (at least for a second time); according to Anna Stevens, who excavated in the cemetery, individual no. 90 was possibly relocated in the South Tombs Cemetery at the time when other family (?) members had died (Stevens 2017, 115). To these main temporal aspects can be added also a third division, which straddles primary and secondary depositions: 'delayed' burials (type e). The lapse occurring from the death of the individual and the act of interment in the grave can also be protracted in time. In ancient Egypt, this type of burial is rather widespread due to the large use of mummification practices, which necessarily require delayed interment of individuals (Ikram \& Dodson 1998; Marshall \& Lichtenberg 2013).

Although the division between 'primary', 'secondary', and 'delayed' burials is effective also for multiple interments (see below), there are other temporal elements that affect the composition and assemblage of multiple depositions. Grouped inhumations in individual graves (direct/indirect, according to their architectural arrangements, see above) stress three temporal aspects: simultaneity (type f), continuity (type $\mathbf{g}$ ), and discontinuity (type $\mathbf{h}$ ).

Simultaneous multiple burial (type f). Simultaneity stresses chronological immediacy and proximity; burials have entered the same funerary space in the same time, in an episodic multiple usage of the same grave. In this case, a direct connection is most probably intended between the burials.

Primary simultaneous multiple burial (type f.1). For instance, in the northern Delta site of Tell el-Balamun, zone III, at the southern end of the transverse room of shaft no. 21, lay two individuals wearing crude face masks made of gold foil, while in the other areas of the same room were other individuals each with a circular hole in the front of their skull just above the forehead. The excavators suggested that they were 'systematically, or even ritually' killed by a blow with a blunt instrument in an act connected to the deaths of the individuals wearing the gold masks (Abd el-Malek Ghattas 1982, 45-9). ${ }^{5}$ These burials may be defined as 'simultaneous multiple burials' as they stress temporal immediacy, a single spot on the timeline: burials containing two or more individuals interred at the same time; this might be by randomness or by a coincident death-event, such as a common disease or a ritual killing. Primary simultaneous multiple burials imply that the individuals died at the same time and were immediately buried in the original intended location. Therefore, the relations between the individuals may be more intermingled, due, for instance, to the same nature of death (see also below modifier $\boldsymbol{\delta}$ ) or shared family/social bonds.

Secondary simultaneous multiple burial (type f.2). Simultaneous multiple burials could also have been the result of planned or emotional events and, by necessity, intentionally grouped together individuals some time after their death. For instance, walled inside one of the side rooms $(\mathrm{Jb})$ of king Amenhotep II's burial chamber (KV 35, Valley of the Kings, Thebes, Luxor) were the bodies of six pharaohs (Tuthmosis IV, Amenhotep III, Sethi II,

\footnotetext{
${ }^{5}$ Unfortunately, the excavators' information provided is rather scant and the dating proposed somewhat vague: i.e. earlier than Late Period (664-332 BC). However, a Roman Period dating seems more likely (van Dijk 2007, $12-13)$.
} 
Merenptah, Siptah, Ramses IV, V, and VI) and an unknown female individual, all gathered from various tombs and earlier caches on a single occasion (see Fig. 04; Piacentini \& Orsenigo 2005, 136; Reeves \& Wilkinson 1996, 198-9). The individuals all clearly belonged to different periods -since their chronological sequence is very well documented in written sources (spanning from 1400 to $1137 \mathrm{BC}$ )- so they did not die contemporaneously, yet the action of the reburial was simultaneous, made at a single point in time by the Theban priests who tried to save these mummies from the widespread robberies taking place in Thebes between 1069 and 950 BC (Strudwick 2013; Miniaci 2007). This type of burial may be classified as 'secondary simultaneous multiple burials', as it relocates non-simultaneously dead individuals to a different place from their original burial location.

Delayed simultaneous multiple burial (type f.3). For instance, in the case of Tonto Basin Salado (AD 1280-1450, Central Arizona), some deceased community members were kept for a period of time in specialized rooms and eventually buried together in a single grave (Loendorf 1998). In this case, it is more appropriate to use the definition 'delayed simultaneous multiple burials', as the time of death of individuals may not be exactly the same, and accordingly this may affect also the type of relation between the individuals. A similar scope can be drawn from work of Stevens (2017) for the suburban cemeteries of Amarna (especially for the North Tombs Cemetery), where the large number of multiple burials may tentatively suggest that bodies were being collected over the course of a few days and buried in the same grave.

Sequential multiple burial (type g). Some single graves containing multiple bodies were re-opened at some distance in time after their first closure, in order to allow a second, third or even more new interments to be made into existing graves, in a continuous, long-term usage of the grave. In this case, the temporal stress is on chronological proximity; consequently, the lapse of time between the original interment and the subsequent reopening(s) should not be too long otherwise the consecutiveness of the action will have been lost (see below type $\mathbf{h}$ ). Two of the main aspects that sequential multiple burials intend to highlight are the intentionality of the re-use of the same funerary space and a common link or a direct connection between the burials. During their excavations of 1910-14 in an area of western Thebes (Luxor), Carter and Carnarvon discovered an unusually large saff-tomb, labelled C37 (Fig. 05; Carnarvon \& Carter 1912, 38, 51, pl. 55; Miniaci 2011, 92-101) containing a large number of burials (64 coffins in total, Miniaci 2011, 84-9). The latest chronological limit for these burials is the reign of Hatshepsut/Thutmosis III (1479-1425 BC), when the tomb was definitely sealed during the construction of the Deir el-Bahari valley temple complex (Miniaci 2016). During this phase the whole of the tomb complex was extensively occupied (including non-normative areas: niche, pit, corridors, passages) by a high number of depositions, which belong to a broad common cultural phase (Miniaci 2018). At the end of the corridor is a room $(C)$ in which a vertical pit $(D)$ gives access to three different underground funerary chambers $(F$ and $E)$. Pit $D$ was piled from bottom to top with 18 coffins (Carter's nos. 41-59, excluding no. 54). One of the upper coffins (no. 53) contained two scarabs, one bearing the name of Hatshepsut's daughter Neferure and the other the prenomen of Tuthmosis III (1479-1425 BC), while one of the lowest coffins (no. 59) contained two scarabs inscribed with the names of Tuthmosis II (1492-1479 BC) and Tuthmosis I (1504-1492 BC). The sequence of deposition in the shaft seems to indicate a progressive filling from the time of Tuthmosis I until the reigns of Hatshepsut and Thutmosis III, when the structure stopped functioning. Thus, it is clear that the burials did not enter the tomb in a single moment, but they were sequentially introduced into the structure (1504 > $1492>1479>1425 \mathrm{BC}$ ).

Intrusive multiple burial (type $\mathbf{h}$ ). Those interments which entered, either accidentally or voluntarily, the grave after a considerable amount of time from its final closure/sealing can be 
labelled 'intrusive multiple burials'; they stress factors of chronological discontinuity of use. Most of the burials which entered the grave long after its first closure have no direct relationship to the original owner or earlier occupants. The practise of intrusive multiple burials is attested in all societies and above all in Egypt, where they are especially attested around the early first millennium BC (ca. 1069-664 BC) (Taylor 2010). A this time, a probable decrease in resources led to a reduction in construction of funerary monuments and gave rise to a massive reuse of previous graves. For instance, one of the underground rooms (I) of the tomb belonging to the funerary priest Huy (TT14, Thebes, Luxor), who lived during the reign of the king Ramses II (1279-1213 BC), was occupied by at least 5 individuals who were buried there more than 200 years (1069-945 BC) after Huy had his tomb built. These individuals occupied non-normative areas, such as the antechamber of funerary room $(\mathrm{J})$ of Huy, where they were deposited above a layer of mud resulting from a flood sealing the burial chamber itself (Betrò, Miniaci \& Del Vesco 2012, 28-34). Nonetheless, intrusive multiple burials may stress also indirect links with the place of deposition, such as the type of site, the ideological importance of the person, proximity to other burials, etc. ( $c f$. Wickholm 2008, for an ideological reuse of Middle and Late Iron Age cemeteries in Finland and Estonia). For instance, in Theban tomb A17, in the proximity of the Temple of Amenhotep II (Consonni 2016), a first phase of use dating to 2055-2000 BC is followed by a phase of disuse or abandonment, which lasted for almost half millennium, and by a phase of reoccupation in the 1550-1500 BC (Fig. 06). Although no immediate elements of continuity between the phases of occupation can be recognised, such a custom follows a precise pattern attested elsewhere in the Theban necropolis: initial use in early-mid Middle Kingdom (20552000 BC) $\rightarrow$ phase of disuse/abandonment $\rightarrow$ reuse in the Second Intermediate Period (16501500 BC) (Miniaci 2016). Therefore, a clear linking element might be perceived or suggested, such as an attempt to establish a fictional kin relationship (?) (cf. the construction of important administrative buildings near or above earlier burials at Cyprus, Osterholtz 2015, $60,260)$.

\section{Sub-parameters sp1-3}

\section{sp1. Number of individuals}

When faced with a high number of individuals in the same funerary feature, scholars have often felt the need to distinguish this type of burial from the rest of the multiple burials, adopting the term 'mass burials'. However, the meaning of the term has varied according to different traditions and cases (Barker, Alicehajic \& Naranjo Santana 2017, 256-7). The main guidelines for the identification of mass burials have often been given by the presence of a minimum number of bodies (Skinner 1987, 267-87; Schmitt 2002, 277-92) and their organisation in the grave (in disordered state, i.e. amassed, c.f. Jessee \& Skinner 2005). For instance, Knüsel and Robb tend to describe a mass grave as a large number of individuals placed tightly together, often in layers and sometimes in a disordered state (Knüsel, Robb 2016, 657). Haglund (2002), instead, simply defines a mass grave as 'a mass of bodies (organised or disorganised) in intimate contact with each other and deposited in the same grave'. The inconsistency and variability of the definition is mainly due to the fact that it has been not developed within a methodological framework; it would repay more careful distinction.. This may be done on a purely numerical base, not on an empirical or assumptive base but following the methods suggested by linguistic anthropology.

Double burial (modifier $\boldsymbol{\alpha}$ ). Two has been perceived since ancient times as an entity different from the multitude, as exemplified by the familiar use of dual in the lexicon of various ancient and modern languages (Indo-European; Afro-Asiatic; Uralic, Kiowa-Tanoan, Micronesian, and Australian; Acquaviva 2017). In the linguistic anthropology approach, the 
structure of a language is often perceived not as arbitrary but rather governed by cognitive constraints (Dimmendaal 2015): therefore, the grammatical use of the dual may mirror an ingrained natural semantic categorisation that straddles the singular and the plural, precisely referring to two of the entities (either objects or persons). When a burial contains two individuals, the concept of multiple burials is not automatically fulfilled, and the term 'double burial' should be privileged over multiple burials.

Mass burial (modifier $\boldsymbol{\beta}$ ). In the same numerical logic, there are pluralities that go beyond the countable, whose size is conceptualized as too large for individual enumeration. The semantic logic of 'mass burials' is not contained in the sheer size (more or less than $x$ individuals) but in the ultimate accessibility of countable individuals (Acquaviva 2017). For instance, in Nubia, during the Classic Kerma Period (c. 1750-1500 BC), very large grave mounds shaped as earthen cylindrical tumuli contained several hundred individuals buried all together in their corridors (Fig. 07), who probably were slain on the occasion of the death of the main owner of the tumulus (Reisner 1923, 137ff; Adams 1977, 202-4; van Dijk 2007, 13-16; cf. Testart 2004). Although these burials may be conceptually classified as type $\mathbf{e}$ 'simultaneous multiple burials', they are customized by the modifier $\boldsymbol{\beta}$ based on numerical perception, therefore they can be classified as 'simultaneous mass burials' (combination of type $\mathbf{f}$ [base] + modifier $\boldsymbol{\beta}$ ), where a large number of individuals are buried together at the same time.

\section{sp2. Age of individuals}

Agglutinating burial (modifier $\gamma$ ). We may consider the possibility that the age can be used to gain worthwhile perspectives in the study of multiple burials. Already, at a cross-cultural level in archaeology and anthropology, Peter Ucko noticed that infant and child burials follow common patterns that distinguish them from the adult ones (Ucko 1969, 270-1). Apart from the case of female individual buried with in utero baby/ies, where those involved in the burial may not necessarily be aware of the foetus, an individual buried with one or more infants is a combination that deviates from the concept of multiple burials. Often this can be associated to some obstetric calamity, where complications related with the birth may have led to the death of both the female individual and the infant/s. However, even when their deaths do not happen simultaneously, pairing adult individual and infant/s in a single grave has often been interpreted as one of the most basic social concerns (Finlay 2000, 418; Quirke 2016, 594-604). Given the special status of infants in society and their close association with adult lives (Crawford 1991; Crawford 1999; Waterman \& Thomas 2011), I adopted a term, 'agglutinating', taken from linguistics, in order to show the 'unmarked plural character' of the burials containing infant/s beside the body of an adult individual. Each infant in the burial may be labeled as the 'singulative element', borrowing again from the linguistic, where it identifies the 'single referent from a mass noun' (Acquaviva 2017). For instance, in the northernmost area of the Theban necropolis, north of the entrance to the Valley of the Kings (Luxor), Flinders Petrie found the burial of a young female individual, who probably lived during the 1600-1550 BC. A small rectangular whitewashed box containing the burial of an infant was lying over the foot of her coffin (Fig. 08; Petrie 1909, 6-10, pls. 22-9). Even in the absence of DNA analysis of the human remains the likelihood that the two individuals are related is high and they may form a unit. Archaeometric analysis carried out on the grave goods, and in particular on the jewellery, revealed that the child's burial equipment shares many features with that of the adult, such as manufacture, form and composition (Tate, Eremin, Troalen, Guerra, Goring \& Manley 2009, 121-8; Troalen, Tate \& Guerra 2014, 219 26). In this case, the using the plain term 'multiple burial' can be misleading for a reader, while it represents an 'agglutinating burial' of an individual and a singulative element. 


\section{sp3. Nature of death/deposition}

Death assemblages may be based also on the nature of the death of the individuals, i.e. multiple individuals -buried in the same funerary structure- who share the same manner and background for their demise.

Bound burial (modifier $\boldsymbol{\delta}$ ). While the simultaneous multiple burials (type f) stress the deposition of multiple individuals in a single episode, this does not necessarily imply that all individuals shared the same mode and manner of death. When the reason of demise is given by natural catastrophes, conflicts, epidemics, genocides, famine, or a disasters ( $c f$. Loe, Boyle, Webb \& Score 2014), the rationale behind this type of multiple burial is not only time (p2) and the number (sp1) -although these are essential elements in the equation- but mainly the nature of death. For instance, in the Deir el-Bahari cliffs at Thebes, one of the graves (no. 507) carved into the rock contained the burials of about sixty individuals, all wrapped in linen. Inscriptions written on the linen, wounds evident on the bodies, and the burial equipment (bows and arrows) suggest that they were soldiers who lived in the earliest years of the Twelfth Dynasty (ca. 1960-1930 BC) and who must have died at the same time, under particular circumstances -such as a battle or a war- (Winlock 1945; Franke 1988, 102). In this case, we are facing a 'bound delayed mass burial' (combination of: type $\mathbf{f}$ [base]+modifier $\boldsymbol{\beta}+$ modifier $\boldsymbol{\delta}$ ).

Stored burial (modifier $\boldsymbol{\varepsilon}$ ). When human remains have become indistinguishable due to mixing of elements, either intentionally or unintentionally, they are usually referred in funerary archaeology jargon as 'co-mingled burials'. However the fragmented, disarticulated, and disturbed burials represent only one aspect of the funerary assemblage, which may or may not affect relations between the individuals and objects in the grave (see Osterholtz, Baustian \& Martin 2014). For instance, mass burials can be artificially created by postdepositional human intervention, as in the case of ossuary burials. In this case, the nature of death cannot always be traced back (see the borderline case-study of Srebrenica as discussed in Barker, Alicehajic \& Naranjo Santana 2017, 264-6). Therefore in this instance, it is not the nature of death, which cannot be always recognised, that plays a key role in the classification of multiple interments but the external anthropic action (Sprague 2005, 74). Therefore, when the agentive human action creates a non-simultaneous reburial of multiple individuals for the purpose of storage or depot, without consideration of social bonds, time and mode of death, the label 'stored multiple burials' may be more appropriate (Walthall 1999, 4).

\section{Add here TABLE 01}

\section{Renegotiation of the role of the body (and funerary equipment) in different types of multiple burials}

The richness of data pertaining to Egyptian funerary archaeology, in particular, has contributed to strengthening the subconscious projection within Egyptian mortuary studies that individuals buried themselves (cf. Parker Pearson 1993), overshadowing the potential complexities inherent in the composition of burials and their links to the living. As consequences, studies have often privileged: a) a segregation of the underground world from that of the living; b) a convergence on the individuality of single bodies, often markedly defined by written texts, associated grave-goods, body containers such as coffins, etc., including in a collective burial context; c) an imperative correlation between objects and the identity (including belief) of the deceased, creating a 1:1 'objects=deceased' relation.

a) Segregation. Funerary architecture and its burial composition cannot be perceived in isolation from the living world (Baines \& Lacovara 2002, 21-22; Harrington 2012; cf. 
Milledge Nelson 2003). The impact of a deceased individual on the living did not cease with his/her death but continued afterwards, influencing the actions and the relations of the living. Tombs and their dwellers are not entirely separable from the political, social and economic aspects of life (Parker Pearson 1999, 193-7).

With the closure of the grave, all the objects in the burial -although they may be typologically separated from each other- became a unique part of the world of the dead, targeting a common objective to evoke social identities and images of death through memories and through the materiality of its constituents, including architecture, bodies, artefacts and rituals (Ekengren 2013, 134). Although constrained and invested of social relations and identity (re)-constructions, human (dead) bodies are subject to the same analytical processes of other artefacts, sharing the same materiality network, which crosses the biological boundaries between animals, artefacts, and people (Sofaer 2006). Exactly like other 'inanimate objects', human bodies have direct agency in shaping and transforming people's lives (Kopytoff 1986, 64-91; Ingold 1996, 183-7; Williams 2003, 1-24); therefore the boundaries between dead bodies and objects break down as they are mutually entangled in a complex network of relations inside the logic of burial assemblage (Jones 2002; Latour 2005, Knappett 2002, 2013). Therefore, bodies and objects in a burial are part of a common material assemblage and their materiality does not differentiate one from the other (Brück 2001; Fowler 2004). The practice of sequential multiple burials (type f) reinforces the transformation of dead bodies into part of the burial equipment, subtracting centrality to the role of the body (Crawford 2007, 89) and disrupting the narrative tied to individual biographies. The passage of time can objectify the value of the body itself. The social context in which the body was placed slowly fades out and, with this process, the body also loses its affective and sensorial links, increasing an 'artefactual' perception.

For instance, in late Middle Kingdom Egypt (1800-1650 BC), the increase and spread of sequential multiple burials (type $\mathbf{g}$ ) influenced the range of objects to be deposited inside the burial, as each new incoming interment met the funerary equipment and bodies from previous interments. A new selection of objects coming from daily life started entering the tomb as part of the funerary equipment: ivory wands connected with the protection of the mother and infant, small figurines of animals and humans, feeding cups, music instruments, walking sticks, small chairs, writing tools (Miniaci \& Quirke 2009; Grajetzki 2014, 156-67; Quirke 2015, 213; Miniaci 2017, 235-84); a real infiltration of the domestic sphere in the funerary domain. The widespread use of sequential multiple burials completely changed the perception of the grave itself, so that it became a sort of 'collective memory container' (Oestigaard \& Goldhahan 2006; Hamilakis 2017). This new aspect of the tomb focussed on temporal continuity: a continuous sequence of individuals buried in the same place (i.e. identity of ancestors and tangible presence of the dead). Accordingly, rituals for individual eternity (basis of an individual stasis) were contracted (visible in a reduction of the equipment created especially for the burial) exactly during the late Middle Kingdom (Bourriau 1991): the individuality and stasis of the eternal ritual for the deceased replaced by motion and communality of multiple depositions.

b) Convergence. Scholars have usually tended towards rather polarised perceptions of single and collective burials, and towards large-scale, rather than micro-level, evaluations of their significance, particularly as regards the widespread change from one burial type to another. Elsewhere I have connected the increase of multiple burials at the end of the late Middle Kingdom (1800 BC), within a system previously based mainly on individual graves, with a profound reorganisation of society, which aimed at emphasising more actively aspects of cohesion and continuity within a - perhaps - larger corporate group (Miniaci forthcoming a; cf. Cauwe 2001; Keswani 2004). Similarly, Kristiansen attributed the shift from the collective 
'Megalithic Culture' burials in Neolothic Danemark to the 'Single Grave Culture' (4000$2800 \mathrm{BC} \rightarrow 2800-2400 \mathrm{BC}$ ) to a transition of a cultivation-based hierarchical society to a more mobile pastoral one (Kristiansen 1984). However, scholars have rarely focussed on the internal characteristics of multiple burials. The method proposed here has the potential to direct attention to the multifaceted meaning inside multiple burials themselves: a body's association in a single grave is not a uniform and inflexible act, set up in an atemporal and univocal context, but it contains divergent social, economic, political, cultural, historical, and religious implications; the same range of implications that may be drawn from the opposition single-multiple burials. The placing of multiple bodies 'can hardly fail to be significant' (Morris 1991, 150) as it constitutes a political (since it is deliberate, but not necessarily always intentional) mnemonic selection of certain components and the segregation of others: 'a way of conceptualizing time through its materiality' (Hamilakis 2017).

Stevens has recently shown the different levels of comprehension that can open when research moves towards a more analytic dissection of the multiple burial context itself. At Amarna (1349-1332 BC), two large non-elite pit-grave cemeteries have recently been excavated. At the North Tombs Cemetery the rate of multiple burials runs close to 40 per cent, while they are much rarer in the South Tombs Cemetery. However, the difference should not be reduced only to the ratio of single burials versus multiple burials, as the nature of the multiple interments from one cemetery to another also varies. At the South Tombs Cemetery, the graves accommodating multiple burials tend to be cut wider than average, with the individuals laid out side-by-side, wrapped separately in simple matting coffins. This cemetery has a normal demographic profile and was perhaps organised largely by family groups, leading to the suggestion that the multiple burials may be family interments (although other explanations are possible). It is difficult to assess whether the individuals were interred at the same time, given the simplicity of the burial architecture - pit graves cut into sand and the disruption of the archaeological record by looting. At the North Tombs Cemetery, the multiple burials have a different character. These graves are often cut only slightly wider than single interments, although sometimes longer than seems necessary. The bodies (mostly two, but up to at least five) are tightly packed, and sometimes wrapped together in the same burial mat, in layers on top of each other (Stevens 2017, 119). Except for one instance when sand layers have been recorded between the corpses, that may indicate simultaneity in the deposition of the bodies, the general arrangement of these burials points towards a classification as primary simultaneous burials (type f.1). A primary simultaneous burial type may derived from an epidemic or other human large-scale events, such as war, conditions that, at least in terms of the latter, are not verified for Amarna. The North Tombs Cemetery displays a restricted demographic profile, dominated by adolescents and young adults, which might point to the cemetery accommodating one or more labourers' communities. Family burial groups are not obvious, given the constrained age profile, but could be present in restricted form. At this particular cemetery, the multiple burials seem to reflect factors other than, or additional to, family closeness in death: people perhaps living away from their core families, probably working to maintain the city, dying because of inadequate living conditions, and buried in a pre-cut graves for hosting deceased who share the time of death (Stevens 2017, 119-20; Stevens \& Dabbs 2018).

c) Imperative correlation. Often, as anthropologists have warned, objects in a tomb tend to mirror the society in which individuals lived more than the buried individuals themselves. Some items placed in the tomb could have been completely unfamiliar to the deceased; for instance, gifts presented by mourners (Ucko 1969, 262-80). The association of objects inside a multiple grave must also be revised according to individual cases. 
The idea inherited from Jens Jakob Asmussen Worsaa, founder of modern scientific archaeology (1843), that the grave is the result of a single event in time can no longer be maintained. Invisible alterations often happened directly at the time of interment, as misappropriation of objects during the funeral/deposition or involuntary damage to the corpse during interment (Näser 2013). A closed context, or an intact context, in funerary archaeology does not represent a magical moment where history stopped running and archaeologists are able to retrieve a pristine past 'as it truly was' ('Pompeii Premise', Schiffer 1985, 18-41; Sommer 2012, 15-34). Even perfectly intact closed contexts reveal only a partial and fractured history, altered over time in deposition and after discovery (restoration, conservation, display), resulting in omission and destruction (notably of liquid and organic materials, $c f$. Hurcombe 2014). If an individual chose to re-use part of an earlier grave, however close or distant in time, it would have been difficult not to disturb previous burial(s). ${ }^{6}$ In archaeology, however, signs of disturbance are too often carelessly translated as a result of 'plundering action'. While archaeologists might attempt to identify a precise time when the burial of a single individual occurred, becoming disassociated from its human cycle and isolated in its context, the same cannot be said when dealing with multiple burials where often several different periods of disturbance may occur. The simple operation of reopening a grave necessarily implies alteration, dispersal and the destruction of a previous context, making it difficult to separate what might be missing from what might not have been included. Accordingly, the nature of the disturbance varies according to the type of multiple burial.

Bearing in mind the above, in principle, primary undisturbed simultaneous multiple burials (type f.1), show no signs of disturbance, except for those generated at the time of interment, which potentially saw movement or breakage of objects/corpses, or due to natural taphonomic causes, such as the gradual dismembering and disarticulation of the body resulting from the defleshing process.

The sequential use of a structure for multiple individuals and for a prolonged -but limitedtime span (type g), may involve minor and major tampering, misappropriation, and reshuffling of the artefacts and bodies, but not necessarily voluntary destruction or removal of the previous contexts. ${ }^{7}$ For instance, grave no. 1379 in the Eastern Necropolis at Deir elMedina (Thebes, Luxor, 1550-1450 BC), which hosted the bodies of one male and one female individual (according to Bruyère), was found sealed and intact, and not subsequently intruded upon by robbers. Despite this, the original burial context had been interrupted, the mummy of the male individual showing signs of having been unwrapped and hurriedly restored after the funeral, and the mummy of the female individual robbed of its jewelry (Fig. 09; Bruyère 1937, 170-5, figs. 95-7). Other easily movable objects may also have been voluntary taken and removed from the original burial equipment.

In the British Museum thirty-six objects can be attributed to the 'late Middle Kingdom' tomb G62 found by Petrie at Abydos (Miniaci forthcoming b). In the absence of precise archaeological information provided by the excavator at the time of discovery, the range of objects apparently seem to belong to a heavily disturbed context: some elements are clearly missing, such as the handle of the mirror and the lids of some toilet vessels. However, most

\footnotetext{
${ }^{6}$ In some instances, later interments could have been simply placed above earlier burials without any immediate -but later visible in archaeology-damage occurring.

${ }^{7}$ Contra, Herbert Winlock, while excavating an 'intact' Twenty-second Dynasty (945-720 BC) sequential multiple burial in Thebes, noticed: 'Four women had been buried there successively, and as each newcomer was brought down the pit for her everlasting rest her undertakers had taken the occasion to drag her predecessor out of their coffins and break up their furniture in the search for valuables. Finally the last occupant was brought down, a spot cleared out in the corner of the room, baskets, wigs, coffins, and pitifully maltreated mummies brushed aside, and his coffin left there' (Winlock 1921, 35).
} 
of the objects belong to a narrow chronological frame, which extends from the late Middle Kingdom (1800-1650 BC) to the mid Second Intermediate Period (1650-1600 BC). The entire range of objects from G62 closely echoes the funerary equipment included in other sequential multiple burials of the same period, notably those from Abydos 416 (Kemp \& Merrillees 1980, 105-60); Abydos E 1 (Tooley 2015, 339-55); Lisht Pit 466 (Quirke 2016, 157-9); and possibly Lisht Pit 885 (Quirke 2016, 176; note that no human remains are recorded for this structure). The absence of objects dating to earlier or later periods seems to indicate that G62 did not reuse an earlier context and did not suffer from later intrusions/reuse ( $c f$. type g). In the case of sequential multiple burials, artefacts are not always clearly related to a single space, to a single identity, and to a precise time, as they have not all been deposited at the same point in the past. ${ }^{8}$ Therefore, the atomic individuality of burial equipment -as perceived by modern scholars- tends to fade out; types of objects grouped together no longer correspond to a definite point in time, to a homogenous segment of society and to a uniform culture (although a single interment also rarely corresponds to single moment in time, see Ucko 1969; Lillios 1999; Sherrat 2012).

In conclusion, a systematic assessment of the manner in which multiple individuals are associated in a single grave can lead to a rethink of social strategies for mortuary practices within a society, involving both objects and humans. The main impulse for the creation of these categories is to find a way through the vast array of inconsistent terminology used in funerary archaeology. The overall aim is to extract a theoretical approach and precise set of methods from a robust dataset, that can find application beyond the borders of ancient Egypt, in order to shed new light both on the interpretation of the archaeological context (including the evaluation of the burial equipment) of multiple burials and on social and political transformations over time and space. The categories have been created in order to be both universal and flexible, since they are based on two permanent universal coordinates (time and -architectural-space) with the addition of variable modifiers of value. I identified three other essential sub-parameters that are flexible and can, where appropriate, modify the two base parameters (the number and age of the individuals and the nature of death/deposition), but other factors may be taken into consideration or added to this list, such as the sex of the deceased. The fluid combination of stable parameters and flexible sub-parameters creates universal and combinable cross-cultural categories, which can be applied to a wide range of cases and societies.

Acknowledgement. I am deeply indebted to Wolfram Grajetzki, Juan Carlos Moreno García, Rune Nyord, and Anna Stevens for reading through earlier drafts of this paper, providing thoughtful commentary. I am grateful to Paul Whelan for improving and checking the English; any mistakes or omissions are my own. Finally, I would like to thank the two anonymous reviewers for their insightful critiques, which greatly improved the structure of the article.

\section{Bibliography}

Abd el-Malek Ghattas, F., 1982. Tell el-Balamoun 1978 (Fouilles de l'Université de Mansoura). Annales du Service des Antiquités de l'Égypte 68, 45-9.

\footnotetext{
${ }^{8}$ Rigorous methods of recording and collecting artefacts will help in decoding some of the multiple stories inside multiple burial contexts, see Betrò, Miniaci 2018.
} 
Acquaviva, P., 2017. Number in language, in Oxford Research Encyclopedia of Linguistics, ed. M. Aronoff.

http://linguistics.oxfordre.com/view/10.1093/acrefore/9780199384655.001.0001/acrefore9780199384655-e-61 <accessed 5.4.2018>.

Adams, W.Y., 1977. Nubia: Corridor to Africa. London: Allen Lane.

Andrews, P., \& S. Bello, 2006. Pattern in human burial practice, in Social Archaeology of Funerary Remains, eds. C. Knüsel \& R. Gowland. Oxford: Oxbow Books, 14-29.

Armelagos, G.J., 2003. Bioarchaeology as anthropology. Archaeological Papers of the American Anthropological Association 13(1) (special issue: Archaeology Is Anthropology), $27-40$.

Arnold, D., 1992. The pyramid complex of Senwosret I. The South Cemeteries of Lisht 3. (Publications of the Metropolitan Museum of Art Egyptian Expedition 25.) New York: Metropolitan Museum of Art.

Arnold, D., 2002. The Pyramid Complex of Senwosret III at Dahshur: Architectural Studies (Publications of the Metropolitan Museum of Art Egyptian Expedition 26.) New York: Metropolitan Museum of Art.

Arnold, D. 2007. Middle Kingdom Tomb Architecture at Lisht (Publications of the Metropolitan Museum of Art Egyptian Expedition 28.) New Haven (CT); London: Metropolitan Museum of Art; Yale University Press.

Baines, J., \& P. Lacovara, 2002. Burial and the dead in ancient Egyptian society. Respect, formalism, neglect. Journal of Social Archaeology 2(1), 5-36.

Barker, C., E. Alicehajic, \& J. Naranjo Santana, 2017. Post-mortem differential preservation and its utility in interpreting forensic and archaeological mass burials, in Taphonomy of Human Remains. Forensic Analysis of the Dead and the Depositional Environment, eds., E.M.J. Schotsmans, N. Márquez-Grant \& S.L. Forbes. Chichester: Wiley, 251-76.

Benthien, C., 2002. Skin: On the Cultural Border Between Self and the World, trans. T. Dunlop. New York (NY): Columbia University Press.

Betrò, M. \& G. Miniaci, 2018. Used, reused, plundered and forgotten: an unusual group of Ramesside coffins from the tomb MIDAN.05 in the Theban Necropolis, in Ancient Egyptian Coffins: Craft Traditions and Functionality. Proceedings of the Annual Egyptology Colloquium at the British Museum, 28 July-29 July 2014, eds. J.H. Taylor \& M. Vandenbeusch. (British Museum Publications on Egypt and Sudan, 4.). Leuven: Peeters.

Betrò, M., G. Miniaci \& P. Del Vesco, 2012. La Missione Archeologica dell'Università di Pisa a Dra Abu el-Naga (M.I.D.AN.) -Campagne VIII-XI (2008-2011)-. Egitto e Vicino Oriente 35, 21-51.

Binford, L.R., 1971. Mortuary Practices: their study and their potential, in Approaches to the Social Dimensions of Mortuary Practices, ed. J.A. Brown. (Memoirs of the Society for American Archaeology 25.). Washington (WA), 6-29. 
Boulestin, B. \& H. Duday, 2005. Ethnologie et archéologie de la mort: de l'illusion des references à l'emploi d'un vocabulaire, in Les pratiques funéraires à l'âge de Bronze en France. Actes de la table ronde de Sens-en-Bougogne, eds. C. Mordant, G. Depierre. Yonne, $17-35$.

Bourriau, J., 1991. Patterns of change in burial costumes during the Middle Kingdom, in Middle Kingdom Studies, ed. S. Quirke. New Malden, 1-20.

Boz, B., L.D. Hager, 2014. Making sense of social behavior from disturbed and commingled skeletons: a case study from Çatalhöyük, Turkey, in Commingled and Disarticulated Human Remains: Working Toward Improved Theory, Method, and Data, eds. A.J. Osterholtz, K.M. Baustian \& D.L. Martin. New York; Heidelberg; Dordrecht; London, 17-33.

Brück, J., 2001. Body metaphors and technologies of transformation in the English Middle and Late Bronze Age, in Bronze Age Landscapes: Tradition and Transformation, ed. J. Brück. Oxford: Oxbow Books, 149-60.

Bruyère, B., 1937. Rapport sur les fouilles de Deir el Médineh (1934-1935). Deuxième partie: La nécropole de l'est (Fouilles de l'Institut Français d'Archéologie Orientale 15.) Le Caire: Institut français d'archéologie orientale.

Butler, J., 1993. Bodies That Matter: On The Discursive Limits of Sex. New York (NY): Routledge.

Carnarvon, Fifth Earl of \& H. Carter, 1912. Five Years' Explorations at Thebes: A Record of Work done 1907-1911. London: Henry Frowde; Oxford University Press.

Castex, D. \& F. Blaizot, 2017. Reconstructing the original arrangement, organisation and architecture of burials in archaeology, in Taphonomy of Human Remains. Forensic Analysis of the Dead and the Depositional Environment, eds. E.M.J. Schotsmans, N. Márquez-Grant, S.L. Forbes. Chichester: Wiley, 277-95.

Cauwe, N., 2001. Skeletons in motion, ancestors in action: Early Mesolithic collective tombs in southern Belgium. Cambridge Archaeological Journal 11(2), 147-63.

Consonni, A., 2016. Precious finds from an early Middle Kingdom tomb in Thebes: reconstructing connections between the dead and their goods, in The World of Middle Kingdom Egypt (2000-1550 BC): Contributions on Archaeology, Art, Religion, and Written Sources, eds. G. Miniaci \& W. Grajetzki (Middle Kingdom Studies 2.), London: Golden House Publications, 13-26.

Crawford, S., 1991. When do Anglo-Saxon Children Count?. Journal of Theoretical Archaeology 2, 17-24.

Crawford, S., 1999. Childhood in Anglo-Saxon England. Stroud: Sutton.

Crawford, S., 2007. Companions, co-incidences or chattels? Children and their role in early Anglo-Saxon multiple burials, in Children, Childhood and Society, eds. S. Crawford \& G. 
Shepherd (IAA Interdisciplinary Series Vol. I: Studies in Archaeology, History, Literature and Art. B.A.R. International Series 1696.) Oxford: Archaeopress, 83-92.

van Dijk, J., 2007. Retainer Sacrifice in Egypt and Nubia, in The Strange World of Human Sacrifice, ed. J.N. Bremmer. Lueven; Dudley, MA: Peeters, 135-55.

Dimmendaal, G., 2015. Semantic categorization and cognition, in The Routledge Handbook of Linguistic Anthropology, ed. N. Bonvillain. London; New York (NY): Routledge, 13-26.

Duday, H., 2006. L'archéothanatologie ou l'archéologie de la mort [Archaeothanatology or the archaeology of death], translated by C.J. Knüsel, in eds. R.L. Gowland, C.J. Knüsel, Social Archaeology of Funerary Remains. Oxford: Oxbow Books, 30-56.

Duday, H., 2008. Archaeological proof of an abrupt mortality crisis: simultaneous deposit of cadavers, simultaneous deaths?, in Paleomicrobiology: Past Human Infections, eds. D. Raoult, D. Drancourt. Heidelberg: Springler-Verlag Berlin, 49-54.

Duday, H., 2009. The Archaeology of the Dead. Lectures in Archaeothanatology. Oxford: Oxbow Books.

Duncan, W.N. \& K.R. Schwarz, 2014. Partible, permeable, and relational bodies in a Maya mass grave, in Commingled and Disarticulated Human Remains: Working toward improved Theory, Method, and Data, eds. A.J. Osterholtz, K.M. Baustian \& D.L. Martin. New York (NY); Heidelberg; Dordrecht; London, 149-70.

Ekengren, F., 2013. Contextualizing grave goods: theoretical perspectives and methodological implications, in The Oxford Handbook of the Archaeology of Death and Burial, eds. L.N. Stutz, S. Tarlow \& F.S. Ekengren. Oxford: Oxford University Press, 17394.

Finlay, N., 2000. Outside of life: traditions of infant burial in Ireland from cillín to cist. World Archaeology 31(3): Issue 3: Human Lifecycles, 407-22.

Fowler, C., 2002. body parts: body parts: personhood and materiality in the earlier Manx Neolithic, in Thinking through the Body: Archaeologies of Corporeality, eds. Y. Hamilakis, M. Pluciennik \& S. Tarlow. New York: Springer, 47-69.

Fowler, C., 2004. The Archaeology of Personhood, London: Routledge.

Fowler, C., 2013. Identities in transformation: identities, funerary rites, and the mortuary process, in The Oxford Handbook of the Archaeology of Death and Burial, eds. L.N. Stutz, S. Tarlow \& F.S. Ekengren. Oxford: Oxford University Press, 511-26.

Franke, D., 1988. Review von W. K. Simpson, Personnel accounts of the Early Twelfth Dynasty, papyrus Reisner IV, Boston 1988. Bibliotheca Orientalis 45, 98-102.

Goldstein, L., 1981. One-dimensional archaeology and multi-dimensional people: spatial organization and mortuary analysis, in The Archaeology of Death, eds. R. Chapman, I. Kinnes \& K. Randsborg. Cambridge: Cambridge University Press, 53-69. 
Gosden, C. \& Y. Marshall, 1999. The biographical role of objects. World Archaeology 31(2), Issue 2: The Cultural Biography of Objects, 169-78.

Grajetzki, W., 2007. Multiple burials in ancient Egypt to the end of the Middle Kingdom, in Life and afterlife in ancient Egypt during the Middle Kingdom and Second Intermediate Period, eds. S. Grallert \& W. Grajetzki. London: Golden House Publications, 16-34.

Grajetzki, W., 2014. Tomb Treasures of the Late Middle Kingdom. The Archaeology of Female Burials. Philadelphia (PA).

Haglund, W.D., 2002. Recent mass graves, an introduction, in Advances in Forensic Taphonomy. Methods, Theory, and Archaeological Perspectives, eds. W.D. Haglund \& M.H. Sorg. Boca Raton: CRC Press, 243-62.

Hallam, E., J. Hockey \& G. Howarth, 1999. Beyond the Body: Death and Social Identity. London: Routledge.

Hamilakis, Y., 2017. Sensorial assemblages: affect, memory and temporality in assemblage thinking. Cambridge Archaeological Journal 27(1), 169-82.

Harrington, N., 2012. Living with the Dead: Ancestor Worship and Mortuary Ritual in Ancient Egypt. (Studies in Funerary Archaeology 6.) Oxford.

Holliday, V.T., 2004. Soils in Archaeological Research. Oxford: Oxford University Press.

Hurcombe, L., 2014. Perishable Material Culture in Prehistory: Investigating the Missing Majority. London: Routledge.

Ikram, S., A. Dodson, 1998, The Mummy in Ancient Egypt: Equipping the Dead for Eternity. London: Thames and Hudson; Cairo: American University in Cairo.

Ingold, T., 1996. Situating Action VI: a comment on the distinction between the material and the social. Ecological Psychology 8, 183-7.

Ingold, T., 1998. From complementarity to obviation: on dissolving the boundaries between social and biological anthropology, archaeology and psychology. Zeitschrift für Ethnologie $123,21-52$.

Jessee, E. \& M. Skinner, 2005. A typology of mass grave and mass grave-related sites. Forensic Science International 152, 55-9.

Jones, A., 2002. Archaeological Theory and Scientific Practice. Cambridge: Cambridge University Press.

Kellehear, A., 2007. A Social History of Dying. Cambridge: Cambridge University Press.

Kemp, B.J. \& R.S. Merrillees, 1980. Minoan Pottery in Second Millennium Egypt (Sonderschrift, Deutsches Archäologisches Institut, Abteilung Kairo 7.) Mainz: Zabern. 
Keswani, P., 2004. Mortuary Ritual and Society in Bronze Age Cyprus. (Monographs in Mediterranean Archaeology 9.) London: Equinox.

Kopytoff, I., 1986. The cultural biography of things: commoditization as a process, in The Social Life of Things: Commodities in Cultural Perspective, ed. A. Appadurai. Cambridge: Cambridge University Press, 64-91.

Knappett, C., 2002. Photographs, skeumorphs and marionettes: some thoughts on mind, agency and object. Journal of Material Culture 7(1), 97-117.

Knappett, C., 2013. Network Analysis in Archaeology: New Approaches to Regional Interaction. Oxford: Oxford University Press.

Knüsel, C.J., 2010. Bio-archéologie: une approche synthétique. Bulletins et Mémoires de la Société d'Anthropologie de Paris 22, 62-73.

Knüsel, C.J., 2014. Crouching in fear: terms of engagement for funerary remains. Journal of Social Archaeology 14(1), 26-58.

Knüsel, C. J. \& Robb, J., 2016. Funerary taphonomy: an overview of goals and methods. Journal of Archaeological Science: Reports 10, 655-73.

Kristiansen, K., 1984. Ideology and material culture: an archaeological perspective, in Marxist Perspectives in Archaeology, ed. M. Spriggs. Cambridge, Cambridge University Press, 72-100.

La Fontaine, J.S., 1985. Person and individual: some anthropological reflections, in The Category of the Person: Anthropology, philosophy, history, eds. M. Carrithers, S. Collins \& S. Lukesal. New York: Cambridge University Press, 123-40.

Latour, B., 2005. Reassembling the Social: An Introduction to Actor-Network-Theory. Oxford: Oxford University Press.

Leclerc, J. \& J. Tarrête, 1998. Sépolture, in Dictionnaire de la Préhistoire, ed. A. LeroiGourhan. Paris: Presses Universitaires de France, 963-4.

Lillios, K.T., 1999. Objects of memory: the ethnography and archaeology of heirlooms. Journal of Archaeological Method and Theory 6(3), 235-62.

Loe, L., A. Boyle, H. Webb \& D. Score, 2014. 'Given to the Ground': A Viking Age Mass Grave on Ridgeway Hill, Weymouth. Oxford: Oxford Archaeology.

Loendorf, C., 1998, Salado Multiple Interments, Kiva 63(4), 319-48.

Marshall, A. \& R. Lichtenberg, 2013. Les momies égyptiennes: La quête millénaire d'une technique. Paris: Fayard.

Meskell, L., 1998. The irresistible body and the seduction of archaeology, in Changing Bodies, Changing Meanings: Studies of the Body in Antiquity, ed. D. Monsterrat. London: Routledge, 139-61. 
Milledge Nelson, S., 2003. Feasting the ancestors in early China, in The Archaeology and Politics of Food and Feasting in Early States and Empires, ed. T.L. Bray. New York (NY), 65-89.

Miniaci, G., 2007. Saccheggi nella necropoli tebana: i sacerdoti alle prese con le ispezioni delle tombe, in Sacerdozio e società civile nell'Egitto antico: Atti del terzo Colloquio,

Bologna - 30/31 maggio 2007, eds. S. Pernigotti \& M. Zecchi. (Archeologia e storia della civiltà egiziana e del vicino Oriente antico - Materiali e studi 14.) Imola, 49-67.

Miniaci, G., 2011. Rishi Coffins and the Funerary Culture of Second Intermediate Period Egypt. London: Golden House Publications.

Miniaci, G., 2016. Note on the archaeological context of tomb C 37, Asasif, in The World of Middle Kingdom Egypt (2000-1550 BC): Contributions on Archaeology, Art, Religion and Written Texts, eds. G. Miniaci \& W. Grajetzki (Middle Kingdom Studies 2.) London: Golden House Publications, 228-33.

Miniaci, G., 2017. Unbroken stories: Middle Kingdom faience figurines in their archaeological context, Company of Images: modelling the ancient imaginary world of the Middle Kingdom. Proceedings of the international conference held on 18th-20th September in London, UCL, eds. G. Miniaci, M. Betrò \& S. Quirke. (Orientalia Lovaniensia Analecta 262.) Leuven: Peeters, 235-84.

Miniaci, G., 2018. Burial equipment of rishi coffins and the osmosis of the 'rebirth machine' at the end of the Middle Kingdom, in Ancient Egyptian Coffins: Craft Traditions and Functionality. Proceedings of the Annual Egyptology Colloquium at the Birtish Museum, 28 July-29 July 2014, eds. J.H. Taylor \& M. Vandenbeusch. (British Museum Publications on Egypt and Sudan 4.) Leuven: Peeters.

Miniaci , G., forthcoming a. Burial demography in the late Middle Kingdom: a social perspective, in Concepts in Middle Kingdom Funerary Culture, ed. R. Nyord. Cambridge.

Miniaci, G., forthcoming b. The Late Middle Kingdom burial assemblage from the tomb G62 at Abydos (BM EA 37286-37320), in Abydos: The Sacred Land at the Western Horizon: Proceedings of the Annual Egyptology Colloquium at the British Museum, 9-10 July 2015, ed. I. Regulski. (British Museum Publications on Egypt and Sudan 6.) Leuven: Peeters.

Miniaci, G. \& S. Quirke, 2009. Reconceiving the tomb in the Late Middle Kingdom. The burial of the accountant of the Main Enclosure Neferhotep at Dra Abu al-Naga. Bulletin de l'Institut français d'archéologie orientale 109, 339-83.

Moore, H., 2000. Ethics and ontology: why agents and agency matters, in Agency and Archaeology, eds. M.-A. Dobres \& J. Robb. London: Routledge, 259-63.

Morris, I., 1991. The archaeology of ancestors: the Saxe/Goldstein hypothesis revisited. Cambridge Archaeological Journal 1(2), 147-69.

Näser, C., 2013. Equipping and stripping the dead. A case-study on the procurement, compilation, arrangement, and fragmentation of grave inventories in New Kingdom Thebes, 
in The Oxford Handbook of the Archaeology of Death and Burial, eds. L.N. Stutz, S. Tarlow \& F.S. Ekengren. Oxford: Oxford University Press, 643-61.

O'Connor, D., 1985. The 'cenotaphs' of the Middle Kingdom at Abydos, in Mélanges Gamal eddin Mokhtar, ed. P. Posener-Kriéger (Bibliothèque d'étude 97; vol. II.). Le Caire, 161-77.

Oestigaard, T. \& F. Fahlander, 2008. The materiality of death: bodies, burials, beliefs, in The Materiality of Death: Bodies, Burials, Beliefs, eds. T. Oestigaard \& F. Fahlander (BAR international series 1768.) Oxford, 1-16.

Oestigaard, T. \& J. Goldhahan, 2006. From the dead to the living. death as transactions and renegotiations. Norwegian Archaeological Review 39(1), 27-48.

Osterholtz, A.J., 2015, Bodies in Motion: A Bioarchaeological Analysis of Migration and Identity in Bronze Age Cyprus (2400-1100 BC). Phd dissertation, University of Nevada.

Osterholtz, A.J., K.M. Baustian \& D.L. Martin, 2014. Introduction, in Commingled and Disarticulated Human Remains: Working Toward Improved Theory, Method, and Data, eds. A.J. Osterholtz, K.M. Baustian \& D.L. Martin. New York (NY); Heidelberg; Dordrecht; London, 1-13.

Parker Pearson, M., 1993. The powerful dead: archaeological relationships between the living and the dead. Cambridge Archaeological Journal 3(2), 203-29.

Parker Pearson, M., 1999. The Archaeology of Death and Burial. College Station (TX): Texas A\&M University Press.

Petrie, W.M.F., 1909. Qurneh (British School of Archaeology in Egypt and Egyptian Research Account 16; London: British School of Archaeology in Egypt.) London: Bernard Quaritch.

Piacentini, P. \& C. Orsenigo, 2005. The Valley of the Kings Rediscovered: the Victor Loret Excavation Journals (1898-1899) and other Manuscripts, translated by S. Quirke. Milano: Università degli studi di Milano.

Polz, D., 2007. Der Beginn des Neuen Reiches: Zur Vorgeschichte einer Zeitenwende (Sonderschrift, Deutsches Archäologisches Institut, Abteilung Kairo 31.) Berlin; New York (NY): Walter de Gruyter.

Quirke, S., 2015. Exploring Religion in Ancient Egypt, Chichester, Malden (MA): WileyBlackwell.

Quirke, S., 2016. Birth Tusks: The Armoury of Health in Context - Egypt 1800 BC. Including Publication of Petrie Museum Examples photographed by Gianluca Miniaci, and drawn from the Photographs by Andrew Boyce (Middle Kingdom Studies 3.) London: Golden House Publications.

Reeves, N. \& R.H. Wilkinson, 1996. The Complete Valley of the Kings: Tombs and Treasures of Egypt's Greatest Pharaohs. London: Thames and Hudson. 
Reisner, G.A., 1923. Excavations at Kerma. Cambridge (MA): Peabody Museum of Harvard University.

Riggs, C., 2014. Unwrapping ancient Egypt. London: Bloomsbury.

Riggs, C., 2016. The body in the box: archiving the Egyptian mummy. Archival Science. International Journal on Recorded Information 2016 (online edition).

Robb, J., 2013. Creating death: an archaeology of dying, in The Oxford Handbook of the Archaeology of Death and Burial, eds. L.N. Stutz, S. Tarlow \& F.S. Ekengren. Oxford: Oxford University Press, 441-58.

Seidlmayer, S.J., 1990. Gräberfelder aus dem Übergang vom Alten zum Mittleren Reich: Studien zur Archäologie der Ersten Zwischenzeit (Studien zur Archäologie und Geschichte Altägyptens 1.) Heidelberg: Heidelberger Orientverlag.

Schiffer, M.B., 1985. Is There a 'Pompeii Premise' in Archaeology?. Journal of Anthropological Research 41(1), 18-41.

Schiffer, M.B., 1987. Formation Processes of the Archaeological Record. Albuquerque: University of New Mexico Press.

Schmitt, S., 2002. Mass graves and the collection of forensic evidence: genocide, war crimes and crimes against humanity, in Advances in Forensic Taphonomy: Method, Theory and Archaeological Perspectives, eds. W.D. Haglund \& M.H. Sorg. CRC Press Book, 277-92.

Schotsmans, E.M.J., N. Márquez-Grant \& S.L. Forbes, eds., 2017. Taphonomy of Human Remains. Forensic Analysis of the Dead and the Depositional Environment. Chichester: Wiley.

Sherratt, S., 2012. The intercultural transformative capacities of irregularly appropriated goods, in Materiality and Social Practice. Transformative Capacities of Intercultural Encounters, eds. J. Maran, P.W. Stockhammer. Oxford: Oxbow Books, 152-72.

Shilling, C., 2008. The challenge of embodying archaeology, in Past Bodies: Body-centered Research in Archaeology, eds. D. Borić \& J. Robb. Oxford: Oxbow Books, 145-51.

Skinner, M., 1987. Planning the archaeological recovery for evidence from recent mass graves. Forensic Science International 34, 267-87.

Sofaer, J.R., 2006. The Body as Material Culture: A Theoretical Osteoarchaeology, Cambridge: Cambridge University Press.

Sommer, U., 2012. Wer hat Dornröschen aufgeweckt? Taphonomie und MainstreamArchäologie, in Taphonomie, eds. H. Stäuble \& S. Wolfram. Kerpen: Welt und Erde Verlag, $15-34$.

Sprague, R., 2005. Burial Terminology: A Guide for Researchers. Oxford, AltaMira Press. 
Stevens, A., 2017. Death and the City: the cemeteries of Amarna in their urban context. Cambridge Archaeological Journal 28(1), 103-26.

Stevens, A. \& G.R. Dabbs, 2018. Tell el-Amarna, spring 2017. Journal of Egyptian Archaeology 104(1), 1-15.

Stoodley, N., 2002. Multiple burials, multiple meanings? Interpreting the early Anglo-Saxon multiple interment, in Burial in Early Medieval England and Wales, eds. S. Lucy \& A.

Reynolds. (Society for Medieval Archaeology Monograph 17.) London: Routledge, 103-10.

Strudwick, N., 2013. Ancient robbery in Theban tombs, in Archaeological Research in the Valley of the Kings and Ancient Thebes: Papers presented in Honor of Richard H. Wilkinson, ed. P.P. Creasman. Tucson (AZ): University of Arizona, 333-52.

Tarlow, S., 1999. Bereavement and Commemoration: An Archaeology of Mortality, Oxford: Oxbow books.

Tate, J., K. Eremin, L.G. Troalen, M.F. Guerra, E. Goring \& B. Manley, 2009. The 17th Dynasty gold necklace from Qurneh, Egypt. ArcheoSciences. Revue d'archéométrie 33, 1218 .

Taylor, J.H., 2010. Changes in the afterlife, in Egyptian Archaeology, ed. W. Wendrich. Chichester: Wiley-Blackwell, 220-40.

Testart, A., 2004. Les morts d'accompagnament. La servitude volontair. Paris: Editions Errance.

Tooley, A.M.J., 2015. Garstang's El Arabah Tomb E.1, in The World of Middle Kingdom Egypt (2000-1550 BC): Contributions on Archaeology, Art, Religion, and Written Sources, eds. G. Miniaci \& W. Grajetzki. (Middle Kingdom Studies 1.) London: Golden House Publications, 339-55.

Troalen, T.G., J. Tate \& M.F. Guerra, 2014. Goldwork in Ancient Egypt: workshop practices at Qurneh in the 2nd Intermediate Period. Journal of Archaeological Science 50, 219-26.

Turner, T., 2011. The body beyond the body: social, material, and spiritual dimensions, in $A$ Companion to the Anthropology of the Body and Embodiment, ed. F. Mascia-Lees. New York (NY): Wiley-Blackwell, 102-18.

Ucko, P., 1969. Ethnography and archaeological interpretation of funerary remains. World Archaeology 1(2), 262-80.

Walthall, J.A., 1999. Mortuary behavior and Early Holocene land use in the North American midcontinent. North American Archaeologist 20(1), 1-30.

Waterman, A.J. \& J.T. Thomas, 2011. When the bough breaks: childhood mortality and burial practice in late Neolithic Atlantic Europe. Journal of Archaeology 30(2), 165-83. 
Wickholm, A., 2008. Reuse in the Finnish cremation cemeteries under level ground: examples of collective memory, in The Materiality of Death: Bodies, Burials, Beliefs, eds. T. Oestigaard \& F. Fahlander (BAR international series 1768.) Oxford, 89-97.

Williams, H.M.R., 2003. Introduction: the archaeology of death, memory and material culture, in Archaeologies of Remembrance: Death and Memory in Past Societies, ed. H.R. Williams. New York (NY): Springer, 1-24.

Winlock, H.E., 1921. The Egyptian Expedition 1920-21. Excavations at Thebes. Bulletin of the Metropolitan Museum of Art 16(11), 29-53.

Winlock, H.E., 1945. The Slain Soldiers of Neb-hepet-Re' Mentu-hotep. (Publications of the Metropolitan Museum of Art. Egyptian Expedition 16.). New York (NY).

Worsaae, J.J.A., 1843. Danmarks Oldtid oplyst ved Oldsager og Gravhфie, Copenhagen.

Zitman, M., 2010. The Necropolis of Assiut: A Case Study of local Egyptian Funerary Culture from the Old Kingdom to the end of the Middle Kingdom (Orientalia Lovaniensia Analecta 180.) Leuven: Peeters.

\section{Captions}

Figure 1. Free-standing chapels and burials in the area A in the floodplain of Dra Abu elNaga hill (Thebes, modern Luxor), drawing of Miriam Colella from Polz et al. 1995, 209, Abb 1.

Figure 2. Plan of the Hogarth's tomb 19 at Assiut, drawing of Miriam Colella from Zitman 2010, vol. II, 29, plan 10.

Figure 3. Plan of the tomb 954 at Lisht, drawing of Miriam Colella from Arnold 2007, pl. $159 \mathrm{c}-\mathrm{e}$.

Figure 4. Sketch of the plan with the contents of the side rooms ( Jb) of king Amenhotep II's tomb (KV 35) drawing of Miriam Colella.

Figure 5. Plan of the saff tomb C 37, from Carnarvon, Carter 1912, pl. 55.

Figure 6. Plan of the chamber E, with the positions of the burials and of the grave goods of the early Middle Kingdom. Tomb A17 in the area of the Temple of Millions of Years of Amehotep II, Luxor-West Bank. Courtesy of dr. A. Sesana - CEFB; GIS and data progessing: A. Consonni, E. Croce, T. Quirino.

Figure 7. Plan of the room A, Tumulux XB, drawing of Miriam Colella from Reisner 1923, pl. 24 .

Figure 8. Plan of the so-called Qurna queen burial, north of the entrance to the Valley of the Kings, from Petrie 1909, pl. 22. 
Figure 9. Plan of the tomb no. 1379 at Deir el-Medina, eastern necropolis, drawing of Miriam Colella from Bruyère 1937, fig. 95.

Table 1. The table shows the type of possible combinations of multiple burials according to the main parameters (space and time) and the sub-parameters (sp1-3).

\section{Short Biography}

Gianluca Miniaci

University of Pisa

g.miniaci@gmail.com

Current position: Senior Researcher in Egyptology, University of Pisa; Chercheur Associé at the Ecole Pratique des Hautes Etudes, Paris and Honorary Research Associate, Institute of Archaeology (IoA), UCL. Editor-in-chief of the series Middle Kingdom Studies (Golden House Publications, London) and co-editor-in-chief of the Journal of Egyptian History (Brill, Boston-Leiden), London; co-director (with Richard Bussmann) of the archaeological mission at Zawyet el-Sultan (Menya, Egypt).

Research interest: Material Culture; Egyptian Archaeology; Middle Kingdom in Egypt; Social History and Archaeology; Theoretical approach to Archaeology; Archaeometry; Museology; Funerary archaeology.

Relevant publications: Le Lettere ai Morti e altre storie di fantasmi nell'Antico Egitto, Paideia Editrice, Brescia 2014; Rishi Coffins and the funerary culture of Second Intermediate Period Egypt, GHPE 17, Golden House Publications, London 2011. As editor: The Arts of Making in Ancient Egypt. Voices, images, and objects of material producers 2000-1550 BC, Sidestone, Leiden 2018; Company of Images: Modelling the Imaginary World of Middle Kingdom Egypt (2000-1500 BC), OLA 262, Peeters, Leuven 2017.

\section{MANUSCRIPT KEYWORDS}

multiple burials

funerary archaeology

ancient Egypt

body

taphonomy processes

objectification of the body

funerary equipment 